\title{
23. Sources of Organic Carbon in the Food Webs of Two Florida Lakes Indicated by Stable Isotopes
}

Mark V. Hoyer, Binhe Gu, and Claire L. Schelske

\section{Introduction}

Carbon cycling pathways in lacustrine systems are complex because there are often multiple sources of organic carbon available to the food webs. Among the techniques used to delineate carbon flows from organic matter to consumers, stable isotope analysis may be the most powerful one because isotope compositions of consumers reflect those of the dietary carbon assimilated and incorporated into their tissues and because no system manipulation is involved. The use of stable carbon isotopes in food web study is based on these premises: (1) there is a broad isotope range among different sources of organic matter (Peterson and Fry, 1987 ) and (2) consumer $\delta^{13} \mathrm{C}$ closely resembles their diets within $1 \%$ (DeNiro and Epstein, 1978). Stable isotope analysis has been successfully applied to the investigations of carbon flows in some lacustrine food webs (e.g., Hecky and Hesslein, 1995).

The objective of this study was to determine carbon sources that supported the food webs of lakes Apopka and Okahumpka, Florida, phytoplankton- and macrophyte-dominated systems, respectively. We used stable carbon isotopes as natural tracers to illustrate carbon flows in each food web.

\section{Study Area}

Lakes Apopka and Okahumpka are located in central Florida and differ considerably in some major limnological characteristics (Table 23.1). Lake Apopka ( $28^{\circ} 39^{\prime}$ 
Table 23.1. Typical Limnological Characteristics of Lakes Apopka and Okahumpka, Florida

\begin{tabular}{lcc}
\hline Parameter (units) & Apopka & Okahumpka \\
\hline Secchi disc depth $(\mathrm{m})$ & 0.26 & Bottom \\
pH & 9.0 & 8.1 \\
Dissolved inorganic C $(\mathrm{mg} / \mathrm{L})$ & 24.7 & 26.7 \\
Alkalinity $(\mathrm{mg} / \mathrm{L})$ & 120 & 51.3 \\
Conductivity $\left(\mu \mathrm{S} / \mathrm{cm}^{2}\right)$ & 340 & 177 \\
Total nitrogen $(\mathrm{mg} / \mathrm{L})$ & 4.03 & 0.95 \\
Total phosphorus $(\mathrm{mg} / \mathrm{L})$ & 0.192 & 0.020 \\
Chlorophyll $a(\mu \mathrm{g} / \mathrm{L})$ & 100.0 & 5.0 \\
\hline
\end{tabular}

$\mathrm{N} ; 81^{\circ} 39^{\prime} \mathrm{W}$ ) has a total surface area of 12,400 ha and an average depth of $1.7 \mathrm{~m}$. This lake is hypereutrophic, with an annual net phytoplankton primary production $300 \mathrm{~g} \mathrm{C} / \mathrm{m}^{2}$ (Gale and Reddy, 1994). The water column is highly turbid, as a combined result of high phytoplankton biomass and frequent resuspension of the organic sediments. Low light penetration severely restricts the growth of benthic algae and macrophytes. Lake Okahumpka $\left(28^{\circ} 45^{\prime} 30^{\prime \prime} ; 82^{\circ} 05^{\prime} 02^{\prime \prime}\right)$ has a total surface area of $271 \mathrm{ha}$ and an average depth of $1.1 \mathrm{~m}$. By contrast to Lake Apopka, Lake Okahumpka is a macrophyte-dominated system with eel grass (Vallisneria americana) covering more than $90 \%$ of the lake surface. As a result of macrophyte growth, phytoplankton biomass is extremely low. Epiphyric algae are the second important primary producer in this lake (Canfield and Hoyer, 1992).

\section{Methods}

Phytoplankton, epiphytic algae, aquatic macrophytes, invertebrates, and fish were collected in 1994 and 1995. Owing to low biomass, pure phytoplankton from Lake Okahumpka and benthic algae from Lake Apopka were not obtainable. Sample preparations and mass spectrometer determinations for isotope ratios have been described in detail by Gu et al. (1996).

${ }^{13} \mathrm{C} /{ }^{12} \mathrm{C}$ ratio is expressed in the conventional delta $(\delta)$ notation, defined as the per mil (\%o) deviation from a standard:

$$
\delta^{13} \mathrm{C}(\% o)=\left(\frac{{ }^{13} \mathrm{C}^{12} \mathrm{C}_{\text {sample }}}{{ }^{13} \mathrm{C} /{ }^{2} \mathrm{C}_{\text {standard }}}-1\right) \times 1,000
$$

The standard is Peedee Belemnite limestone. The analytical precision of these measurements was $0.1 \%$. 


\section{Results and Discussion}

The average $\delta^{13} \mathrm{C}$ of consumers in Lake Apopka ranged from -15 to $-8 \%$, reflecting carbon source integrated from different phytoplankton signals $(-14$ to $-3 \%$ ) (Fig. 23.1). Aquatic plants and benthic algae are sparse in this lake and were unlikely to be important to the growth of fish. The small variation in $\delta^{13} \mathrm{C}$ among the planktivores (sunfish, gizzard shad, and least killifish) was indicative of feeding similarity. Blue tilapia is known by its high feeding plasticity, and the broad range of $\delta^{13} \mathrm{C}$ suggested that there was diet variation within the population in Lake Apopka. Although a small percentage of the individuals had the cattail signal $(-26 \%)$, most of them derived their carbon source from plankton production. The two benthic feeders (white catfish and brown bullhead) had the $\delta^{13} \mathrm{C}$ resembling the phytoplankton signal. Similarly, piscivores also displayed $\delta^{13} \mathrm{C}$ signals, reflecting a phytoplankton-based food chain.

The $\delta^{1.3} \mathrm{C}$ of the consumers in Lake Okahumpka fell into a narrow range with one exception. Most of the invertebrates and all fish species $(-18$ to $-16 \%$ ) showed a clear dependence on the epiphytic algal carbon $(-19$ to $-14 \%)$ (Fig. 23.2). Despite its high abundance, the eelgrass (-8\%o) was basically unexploited by consumers. An unidentified species of snail had a $\delta^{13} \mathrm{C}(-12 \%)$ at the midrange between epiphytic algae and the eelgrass, suggesting that it obtained

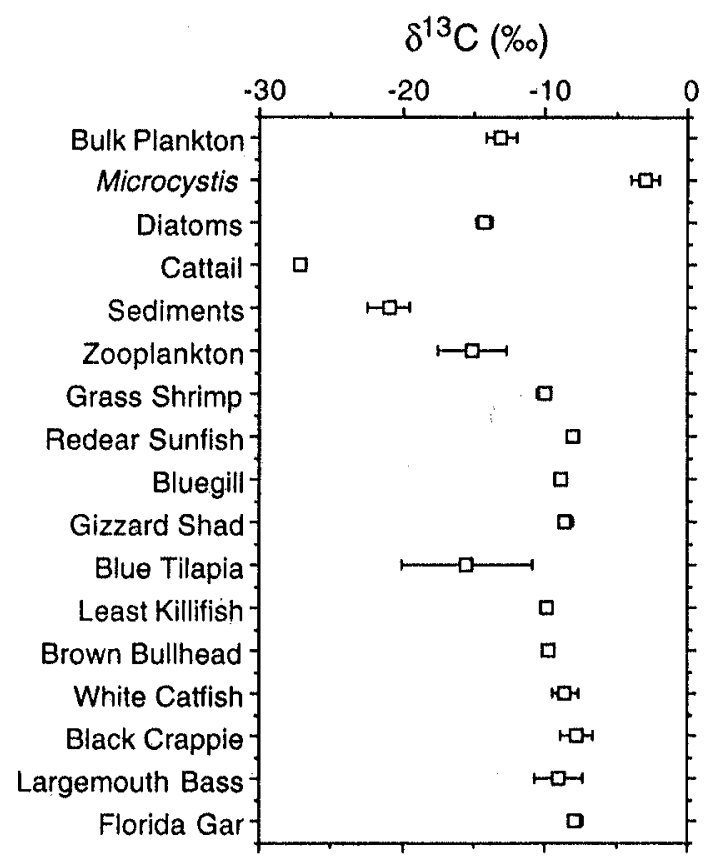

Figure 23.1. Stable carbon isotope ratios of organic matter and consumers from Lake Apopka (mean \pm ISD). 


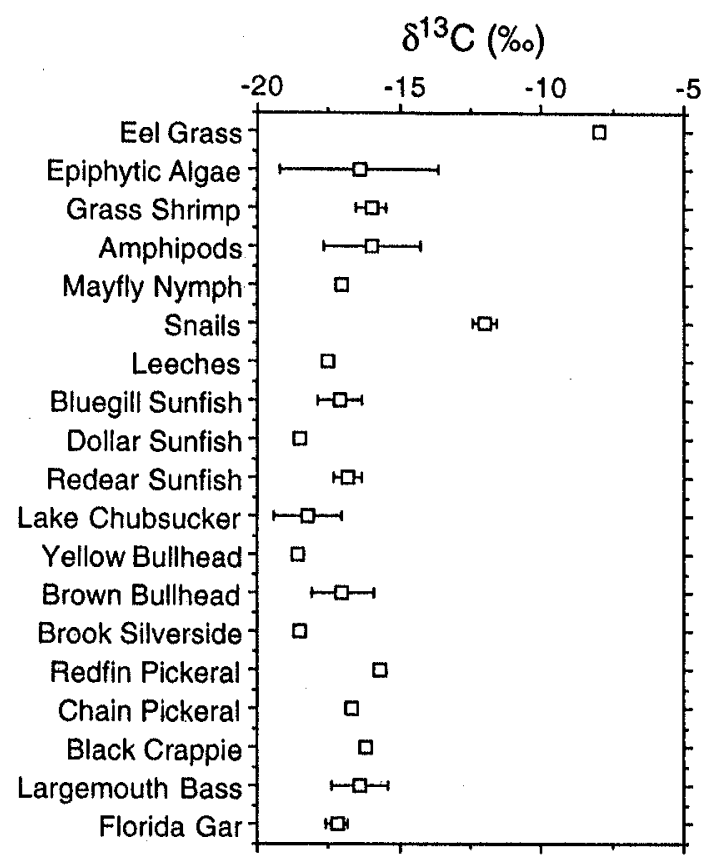

Figure 23.2. Stable carbon isotope ratios of organic matter and consumers from Lake Okahumpka (mean \pm ISD).

approximately equal amount of its dietary carbon from each source. The large difference in $\delta^{\prime \prime} \mathrm{C}$ between the carnivorous fish and snail indicated that the snail biomass was not transferred to a higher trophic level.

Our isotope data revealed two major carbon pathways from primary producers to consumers in the study lakes. Phytoplankton and epiphytic algae were the energy sources fueling the food webs in lakes Apopka and Okahumpka, respectively. The dependence of consumers on phytoplankton carbon in Lake Apopka is not surprising because phytoplankton is the only dominant primary producer in this hypereutrophic lake. Other organic sources, including terrestrial materials, macrophytes, and benthic algae, are not abundant. Only a few percentages of blue tilapia showed dependence for growth on cattail detritus.

By contrast, consumers in Lake Okahumpka showed heavy dependence on epiphytic algal carbon. It is possible that the food web may also derive some carbon from phytoplankton. However, feeding on the dilute phytoplankton is more energy expensive than feeding on the abundant epiphytic algae from the macrophyte surface, which are also nutritionally more valuable than phytoplankton (Hecky et al., 1993). The most abundant macrophyte, eelgrass, was not used by the consumers to any great extent. The lack of trophic linkage between the consumers and aquatic macrophytes in many aquatic systems can be explained by the low 
nitrogen and high structural carbon contents in aquatic macrophytes (Hecky and Hesslein, 1995).

In conclusion, our results indicated that stable carbon isotope compositions of lake biota are excellent indicators of carbon flows in our study lakes. This technique provides insight into the actual carbon sources supporting the growth of consumers and has the advantage over the conventional methodologies in elucidating energy pathways in aquatic systems that receive contributions from different organic sources.

\section{References}

Canfick, D.E., Jr.; Hoyer, M.V. Aquatic macrophytes and their relation to the limnology of Florida lakes. Florida Department of Natural Resources, Tallahassee, FL; 1992.

DeNiro, M.J.; Epstein, S. Influence of diet on the distribution of carbon isotopes in animals. Geochim. Cosmochim. Acta 42:495-506; 1978.

(iale, P.M.; Reddy, K.R. Carbon flux between sediment and water column of a shallow, subropical, hypereutrophic lake. J. Environ. Qual. 23:965-972; 1994.

Gil, B, Schelske, C.L.; Brenner, M. Relationships between sediment and plankton isotope ratios $\left(\delta^{13} \mathrm{C}\right.$ and $\left.\delta^{15} \mathrm{~N}\right)$ and primary productivity in Florida lakes. Can. J. Fish. Aquat. Sci. $53: 875-883 ; 1996$.

Hecky, R.L,; Hesslein, R.H. Contributions of benthic algate to lake food webs as revealed by stable isotope antlysis. J. North Am. Benth. Soc. 14:631-653; 1995 .

Hecky, R.L.. Campbell, P.; Hendzel. L.L. The stoichiometry of carbon, nitrogen, and phosphorus in particulate matter of lakes and oceans. Limnol. Oceanogr. 38:709-724; 1993.

Peterson. B.J.: Fry, B. Stible isotopes in ecosystem studies. Annu. Rev. Ecol. Syst. 18:293$320 ; 1987$. 